\title{
ПОЧАТКИ КИРИЛСКЕЙ ПИСМЕНОСЦИ РУСНАЦОХ У БАЧКИ И СРИМЕ ОД ПОЛОВКИ ХVІІІ ПО ПОЛОВКУ ХІХ ВИКА
}

У статї ше презентує материяли котри шведоча о початкох писменосци Руснацох у Бачки и Сриме, у перших сто рокох їх пребуваня на тих просторох. У рускей лингвистики тому питаню нє пошвецене достаточно уваги. Правда, у тим чаше тота писменосц лєм починала и ище нє мала ушорени норми и нє посцигла окремни досяги, алє зачуване заслужує наукову увагу. У официйней дїялносци грекокатолїцкей церкви и општинскей администрациї превладовала латиница и латински язик. И у приватней преписки духовних особох углавним преовладовал латински язик. Значну часц кирилскей писменосци Руснацох у наведзеним периодзе творя литературне и лїтописне нашлїдство: рукописни зборнїки духовней прози и поезиї и народни лїтописи, цо уж часточно було предмет наукового спатраня и ту го нє будземе окреме споминац.

У тим прилогу пошвециме увагу кирилскей писменосци, преважно у домену церковней и општинскей администрациї, и у приватних писмох. Тот материял интересантни як корпус за анализу початкох розвою писменосци. Мож провадзиц як поєдинци дакеди присподобйовали язик и ортографию конкретней ситуациї. У даєних текстох превладую елементи церковнославянского язика у його русинскей редакциї карпатского ареалу, з елементами бешедох Русинох на Горнїци або менєй чи вецей присутних прикметох народней бешеди Руснацох у Бачки и Сриме. У комуникациї зоз православнима Сербами Руснаци хасновали елементи характеристични за славеносербски язик и його ортографию. У прилогу пре лєпшу илустрацию наведзени характеристични приклади.

Ключни слова: Руснаци у Бачки и Сриме, кирилска писменосц, церковнославянски язик, народна бешеда, славеносербски язик.

The article presents the material that sheds light on the beginnings of literacy of the Ruthenians from Bačka and Srem in the first hundred years of their life in this area. In Ruthenian linguistics that issue has not been sufficiently researched so far. It is true that at that time their literacy was at its beginnings and that it did not have regulated norms nor did it achieve high goals, but what was preserved deserves scholarly attention. In the official activities of the Greek Catholic Church and the municipal administration Latin script and the Latin language prevailed. Even in private correspondence of clergymen Latin was mainly used. A significant part of Cyrillic literacy of the Ruthenians in that period consists of literary and chronicle heritage: manuscript collections of religious prose and poetry and folk chronicles, which have already been the subject of scholarly observation and are not reviewed here.

In this article we focus on Cyrillic literacy, mainly in the domain of church and municipal administration, as well as in private correspondence. This material is interesting as a corpus for the analysis of the beginnings of literacy in which one can trace how some individuals in certain cases adapted language and orthography to a particular situation. In some texts we can see the predominance of the elements of the Church Slavonic language in its Ruthenian recension of the Carpathian area with elements of the Ruthenian dialect in Hornjica or more or less present features of the Ruthenian vernacular in Bačka and Srem. In communication with the Orthodox Serbs, the Ruthenians used the elements characteristic of the mixture of the Russian Church Slavonic language with the Serbian vernacular and its orthography. For the purpose of better illustration, characteristic examples are given in the appendix.

Keywords: Ruthenians in Bačka and Srem, Cyrillic literacy, Church Slavonic language, vernacular, mixture of the Russian Church Slavonic and the vernacular Serbian language. 
Од початку присельованя 303 просторох сиверовосточней Угорскей до Южней Угорскей, до Бачки и Сриму, Руснаци у местох дзе ше населєли у векшим чишлє сновали свойо грекокатолїцки парохиї и конфесийни школи, хтори по початок XX вика були главни центри їх писменосци. Религийна припадносц, односно позиция медзи християнским Востоком и Заходом, охабели шлїди и у їх писменосци. У официйней церковней и шветовней комуникациї и администрациї, та аж и у медзисобней приватней преписки руского священства, од самого початку преважно хаснована латиница, найвецей латински, а менєй нємецки и мадярски язик. У вельо меншей мири присутна кирилица, на церковнославянским язику або на мишанїни церковнославянского з елементами народней бешеди Руснацох на тих просторох и язика Русинох у сиверовосточней Угорскей.

О латинскей писменосци у приватней преписки руского священства у Бачки у другей половки XVIII и на початку XIX вика зме опубликовали окремну статю (Рамач 2020). На рукописне нашлїдство Руснацох у Бачки и Сриме, углавним на зборнїки духовней поезиї и прози и на народни хронїки перши обрацели увагу Володимир Гнатюк (Гнатюк1898; 1902) и Иван Франко (Франко 1899; $1906)$ на концу XIX и початку XX вика. За руску духовну рукописну поезию ше интересовал чешски науковец Франтишек Тихи (Тichý 1928; 1931; Тихи 1932). У другей половки XX вика на тоту файту народней литератури обрацали увагу Михайло Ковач (Ковач 1973; 1977), Александер Дуличенко (Дуличенко 2002; 2009), Юлиян Тамаш (Тамаш 1997: 41-69), Юлиян Рамач (Рамач 2002: 541-553 ) и Янко Рамач (Рамач 2010; 2011; 2016; 2018; 2018a). Анамария Рамач Фурман обявела єдну роботу у хторей дава лингвистичну анализу рукописного зборнїка з другей половки XIX вика (Рамач Фурман 2019).

У тим прилогу окремна увага будзе пошвецена приватней преписки и урядовим текстом церковней або локалней општинскей администрациї котри писани $з$ кирилку на церковнославянским або русинским/руским язику од половки XVIII по половку XIX вика.

Найстарши зачувани документ Руснацох у Бачки на кирилки - писмо керестурского пароха Георгия Росия зоз септембра 1756. року, пейц роки по официйним присельованю Руснацох до Керестура и снованя першей грекокатолїцкей парохиї. Роси написал писмо Янкови Скрипкови, игуменови манастира у Мария Повчу (Máriapócs - нєшка у сиверо-восточней Мадярскей). Написане $є$ на церковнославянским односно на тогочасним кнїжним язику Русинох Мукачевскей епархиї, котри уствари мишанїна церковнославянского 303 елементами народного язика Русинох у сиверовосточней Угорскей. Писмо уж було публиковане у цалосци, а пре його значносц ту приложиме виривки 3 нього и обрациме увагу на даєдни язични прикмети. Интересантне же Роси лєм по даскельомешачним пребуваню у Керестуре и одредзених контактох 3 православнима Сербами з околних населєньох уноши до писма на русинским даєдни елементи сербского язика, поведзме "фала л қnо”. Мож предпоставиц же то зробел же би свойому предпоставеному и на таки способ илустровал часц реалносци у котрей жил. У писме Скрипкови Роси описує свойо положенє и обставини у парохиї до хторей го послал мукачевски епископ. Наводзиме виривки: 
„Радуй ся, весело скакай для ут $\mathbf{k} x ы$ вс $\mathbf{k} x ъ$ нашихъ жый фала л $\mathbf{k n o ~ з а ~ в с я . ~ Н а ~}$ мершынах раикихъ мушу ся рад не рад яко ворон послатый изъ Ноевого ковчега забавляти, хочай и часъ бы быль юж ко братолюбїо вашему ся вертати." (...) „Я тое ся дознавшы, постеригъ и попа рачкого со аппараты и ладкою поимати и моєй парохӥи на ланцъ всадити до арешту дал ..." (Удвари 1989: 253).

Георгий Роси треци по шоре священїк котри службовал у грекокатолїцкей парохиї у тедишнїм Вельким Керестуре - нєшкайшим Руским Керестуре. Остало о нїм записане же бул монах, образовани: знал латински, русински и мадярски язик. Пре свойо справованє и насилнїцке одношенє гу православному священїкови Димитрийови 303 сушедного валалу, котри потайно приходзел и подзельовал обряди у його парохиї, Роси бул наяр 1759. року врацени до Мукачевсного манастира, одкаль ту пришол (Gavrilović 1977: 159-163; Костельник 1998: 108-111).

Окрем того писма, з часу кед Руснаци грекокатолїки у Бачки були под юрисдикцию римокатолїцкей Калочскей архиепископиї (1751-777), у парохийних архивох у Руским Керестуре и Коцуре нє зачувани документи писани на кирилки або на латиници. У Архиве Калочскей архиепископиї з наведзеного периоду зачувани числени документи котри ше одноша на тоти два грекокатолїцки парохиї, алє писани углавним на латинским, ридше на мадярским язику.

Матични кнїжки ше у керестурскей парохиї почали водзиц од 1767. року, алє перша нє зачувана. Гавриїл Костельник у свосй Хронїки керестурскей парохиї наводзи же ю 1915. року мал у рукох (Костельник 1998: 96), а у своєй приповедки Атафия - старого попа дзивка наводзи кратки випис зоз нєй, писани $з$ кирилицу на церковнославянским язику: „Року 1767. Мияа Декембрій Азъ їєрей Мїхаиль Мучон ‘ парохъ в велико Керестурскій ... року у миа тогожде дня 1 окрестихъ и миропомазахъ раба божог(о) Андрея рожденого отъ род(ителей) закон(но) венчани(хъ) Молнаръ Иосифъ и Маріии жени его. Кре(стний) отецъ и Кр (естна) мати биша Папь Мігаль и Агафія старого попа д ъвка" (Костельник 2011: 109). Тот виривок єдине свидоцтво о язику и ортографиї першей керестурскей матичней кнїжки.

Друга матична кнїжка кресцених, винчаних и умартих зачувана по нєшка, водзена на церковнославянским язику од 20. януара 1779. року по 11. децембер 1782. року, а 16. децембра того року нови управитель парохиї Силвестер Бубанович почал ю водзиц на латинским язику и од теди так предлужене. През спомнути штири роки (1779-1782) до кнїжки уписовали пейцме священїки: Яков Силваши, Лука Сташински, Янко Надь, Димитрий Попович и Михайло Палїнкаш (Миз 2016; Костельник 1998). У їх церковнославянским язику нє находзиме елементи народней бешеди прето же ше у матрикули записовало по узвичаєних формулацийох за кресценє, винчанє и хованє, найчастейше: "Азъ Иєрей (мено) дня ... окрестихъ и миромпомаз[ахъ] (мено) $\mathbf{w}$ род[ителе]й зак[онно] в 'ънч[анихъ]" и подобне, або: "Азъ Иерей (мено) пов 'ънчахъ або погребохь итд.

У Архиве грекокатолїцкей парохиї у Руским Керестуре нє пренайдзени тексти 3 домену церковней администрациї з XVIII вика писани з кирилку на руским/русинским язику. Зоз 90-их рокох XVIII вика зачувани два контрак- 
ти керестурскей церковней општини: зоз сербским иконорезачом Арсенийом Марковичом з 1791. року и маляром Арсенийом Теодоровичом Пантасичом 3 1793. року (АПРК, 1791; 1793, без сигнатури). Обидва писани з латиницу, на вариянти тогочасного сербского административного язика, алє подписи уметнїкох 3 кирилку, з церковнославянским писмом. Гавриїл Костельник наводзи обидва контракти и своєй Хронїки керестурскей парохиї (Костельник 1998: 71-74). Ниа, виривок $з$ контракту з маляром А. Теодоровичом:

„1. Obecsuge Sze Gospodar Arsenia Pantashits Malyar na Szvodu Gore Szveru Trogiczu u csetiri ugla, Csetiri Evangeliszta S prostimi Cziratami kako u Bagu stoge u Svodu...".

Перша новинска вистка о Руснацох у Бачки обявена у сербских новинох "Сербскія новины" у Бечу 1792. року, у котрей ше спомина о церемониї кладзеня фундаментного каменя за нову грекокатолїцку церкву у Куцуре (Цап 1996: 26-27). Текст писани на славеносербским односно тогочасним кнїжним сербским язику. Аутор нєпознати, а предпоставя ше же би могол буц коцурски парох Лука Сташински (Миз 2016: 305-306) або даєден други руски священїк, а можебудз аж и католїцки священїк котри бул присутни на церемониї и обрацел ше гу присутним, як ше наводзи, на славянским язику. Анї у тим тексту нє находзиме елементи руского народного язика. Прикладаме виривок: „У Бачкои вармен $\mathbf{k} u$, сел४ к४и ври дне 2 септембрї положиосе каменъ во основанїе восточне иеркве.

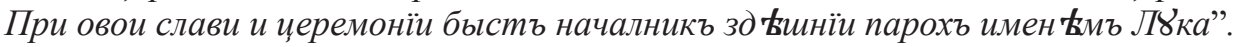

У приватней преписки грекокатолїцкого руского священства у наведзеним периодзе ше частейше хасновало латински, дзекеди з интерполациями на народней бешеди або на мишанїни народного язика з церковнославянским язиком (Рамач 2020), алє зачувани даскельо приклади преписки на народней бешеди або мишанїни народней бешеди 3 елементами церковнославянского або и русинского язика карпатского ареалу.

Коцурски парох Лука Сташински 1792. року написал писмо свойому кумови Петрови Копчайови, парохови у Керестуре (Костельник 1998: 121-123; Миз 2016: 183-184), котре на карпаторусинским язику, з елементами церковнославянского. Ту вшелїяк треба надпомнуц же Л. Сташински и П. Копчаї по походзеню з горнїх крайох. Там закончели нїзши школи, а студиї теологиї у Бечу, кед прешли з юрисдикциї Мукачевскей под юрисдикцию грекокатолїцкей Крижевскей епархиї. По пошвецаню були намесцени на парохиї медзи Руснацох до Бачки, до Коцура и Керестура (Костельник 1998: 121-123; Миз 2016: 183184, 305-306). Гоч уж дзешец роки були на служби медзи Руснацами у Бачки, у писаню хасновали русински кнїжни язик, котри ше у тим чаше хасновало у рамикох Мукачевского владичества. У їх текстох нє находзиме очиглядни елементи бешеди Руснацох у Бачки. Остава отворене питанє чи вони и у контактох 3 народом чували свой карпаторусински язик, чи почали прилапйовац бешеду тутейших Руснацох.

Сташински ословює Копчая зоз „Превелебный Пане Швогре и Любезн тиій Пане К४ме”, а далєй пише: „Маль емъ сище нам треніе шби сме теперъ на окончанїо С [втихъ] $\mathbf{w n} \mathbf{8}$ стовъ рано у нед $\mathbf{k} л ю$ с Процесиовъ С [втовъ] пошли до КерестУра вамегш, коже и вы сте уробили; але понеже многи люде с 


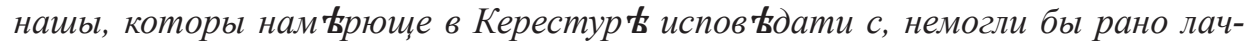
нимъ сердцемь толико пУтовати, ани бы доволного час $\mathbf{8}$ немали на испов $\mathbf{6}$ Св[]т४. Сего ради Превелебности вашей, Пане К४ме, влм же мы с помощїю Б[о]жїю завтра, то есть у с бботष на нощъ, естли не б४де дождь, процеесію до Керест Швегерину зо солоткима Ей Чадами шстаю Пр[евеле]б[но]сти Вашей.

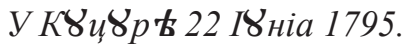

В трный К४ мъ ЛУка Сташин[ский].

Але поциганивъ ємъ с, бо неб४д४ наказовати, знамъ добр ж же ми тото шпростите ичианство, маю роботы дост дрУгей” (АПРК, без сиг., Коцур, 22. 06. 1795).

У другим писме, котре Л. Сташински писал П. Копчайови на латинским язику, цали пасус писани на карпаторуским язику, з кирилку. Ту вон поволує свойого кума же би ше догварели як помогнуц Я. Радваньови, богословови або уж младому священїкови, (Миз 2016: 263), хтори ше зберал на драгу на Горнїцу, и пише: "То коси м४сить быти, мы го такъ къ сиротУ незохабиме, итоси м४симе ४робити, лем бы сме мы могли, Превебыли Пане К४ме, въ едно побесидовати. Сего ради паки, и паки смиренно прош рачте прӥити къ намъ а теперь поздравте ми любезно мою краснУ к४мицу зъ ей солодкима чадами.

Іа шстаю у К४иур 12 Nовемвріа 1795

Превелебности Вашей Покорный К४мъ Л४ка" (АПРК, без сигнатури, 12. ХІ 1795).

Мож предпоставиц же високообразовани людзе у таким дружтве у бешеди хасновали тот кнїжни язик, у окремних нагодох можебудз дакеди и латински, алє вироятно нїгда нє дознаме хтори язик тоти двоме священїки, шовгрове и кумове, хасновали у медзисобней бешеди. Найблїжей правди же то бул їх мацерински русински, котри научели у родзеним краю, на Горнїци.

Керестурски парох Петро Копчаї 1806. року написал писмо свойому синови Янкови, котри бул у школи у Калочи, по латински, а на концу писма наводзи хто го ище поздравя: „,Te autem salutant Cantor et Cantorissa tui compatres, hanyicska мала твоє креснтко" (АПРК, без сиг. 28. 07. 1806). Интересантне же мено hanyicska написане з латиницу, а далєй три слова $з$ кирилку. У другим писме синови, 1808. року, оцец Петро спомина же ма нову служнїцу и наводзи: „ale to trupocsok, veliki, nezna ничъ”. Далєй у писме пише и о панїматки Гаднянскей по руски/русински, з латиницу, з мадярским правописом: „Gadnajszka hodit jak bludna ovcza, nema miszcza nigde" (Рамач 2020: 399). Очиглядне же П. Копчаї у писмох на латинским язику, и кед уруцовал даскельо слова на руским/русинским язику, то було на карпаторусинскей вариянти, найчастейше з латиницу, 3 мадярским правописом. То анї нє чудне, прето же Петро по основней школи, котру закончел на русинским язику, дальше школованє закончел на латинским язику, а у стреднсй школи учел и мадярски.

Янко Копчаї младши, уж як млади священїк, кед бул кратки час 1818. року владиков секретар, пише оцови Петрови на латинским язику длугше писмо о своєй роботи, о новосцох у владичестве, и на концу о обставинох на влади- 
ческим маєтку у Ткалцу, дзе бул дочасно поставени место младого управителя котри трагично погинул. На концу писма спомина о тогорочним урожаю и закончує з виреченьом на русинским язику, з кирилку: „Мало Татарки за каш૪ и доброй сливовици которой буде до 10 аковой”. Интересантне же Янко, родзени у Керестуре, пише нє на бешедним руским язику, алє на карпаторусинским, котри нїгда нє учел у школи, а могол го лєм чуц и дацо научиц од оца и мацери, кед же дома так бешедовали (Костельник 1998: 124-127).

Гоч у административней пракси грекокатолїкох у Бачки при концу XVIII и на початку XIX вика преважно хасновани латински язик, пренашли зме даскельо квити або потвердзеня писани на кирилки на бешеди Руснацох у Бачки з елементами церковнославянского язика. Очиглядне же то нє писал парох, а мож предпоставиц же писал церковни тутор. Наводзиме документ:

„Трошакъ Церквеного тутора Раи Мишки Керестурского котри по церковней страни ходиль и трудился лета 1808.

15 мая да наидетъ на иеркву вапно

20 мая у Черевици с контрактомъ за три дни

1ф[оринт] 30 тр[айиари].

24 мая Церковни туторъ (... ) з Чизмаром

за два дни

1 p. 30 tp.

5 юния по вапно с кочом до три дни

$2 \phi$.

9 юния с тимъ истимъ посломъ

1 p. $30 \mathrm{tp}$.

1 p. 30 tp.

13 юния с тим истим послом

20 юния До Варадина по (...) и с нимъ назать

до Керестура идучи

2 p. 12 tp.

Сума 11 ф. 42 тр.

Више писана сума по иерковней роботи (...) се припознаю

У Керестуру 30 дек[емвріа] 1808." (АПРК, без сигнатури, Керестур, 30. 12. 1808).

У официйней комуникациї церковни общества або поєдинци дакеди ше гу предпоставеней церковней власци обрацали з молбами або жалбами на народней бешеди з елементами церковнославянского або и славеносербского язика. Александер Дуличенко у даскелїх прилогох публиковал часци з таких материялох, як и материяли з рукописного нашлїдства, алє нє уходзел глїбше до язичней анализи (Дуличенко 2002: 163-176).

Керестурски помоцни учитель Дюра Надь ше 1842. року обрацел з молбу гу крижевскому владикови и модлєл же би го владика меновал за учителя у грекокатолїцкей парохиї у Петровцох. Ту наводзи свойо заслуги за насельованє Руснацох до того места. Прикладаме виривки з молби:

„На кога над $\mathbf{k} ю с я$, яко на милость $N$ қовогъ Преосвященства, убо день приходитъ, а нощъ приближается. Така и времена челов ьческая ४крачаются, а старость Приближается, а найпаче У сиромаштв а камо старима, тако и на себе гледаюћъ, къ старости приклоняю глав 
Персам их Преосвященичеств $\mathbf{8}$ да би толико Милосердиа о мн $\mathbf{k}$ могли им $\mathbf{k} т и$, и на мое Школе и сиромаство погледати, и мене за ४чителя место ४ Петрови $\mathbf{6}$ дати и потвердити како ми и обећано от $\mathrm{N}$ ъовог Преосвященства било, да ћю я ту штаиию добити, а особито сам и заслУжио, кои я за истУ ПетровачкУ селидб8 трудио се ..." (АКЕ, 42/1842). Учитель Надь ше трудзи писац на славеносербским язику, цо вироятно ребел свидомо, бо писал крижевскому владикови, котри нє познал добре руски язик. У писаню хаснує и сербске $\mathbf{h}$, a и ят (\$) пише барз подобно як $\mathbf{h}$.

Керестурски биров и ешкути/пришагнїки ше 1852. року обрацели з молбу гу крижевскому владикови и модлєли же би Дионизия Шовша (Миз 12016: 341) намесцел за керестурского капелана. Ниа, виривок з молби: "Прешсвящен $\mathbf{k} и и$ владико на вашу C[вя]тость огповаемъ абы рачили наше желанїе изполнити и шпомян преподати. (...) Вопрочемъ препор Учаемося Ваше стадо д४ховны швиы и иилуеме с [вя]т (АКЕ, 195/1852). Долу шлїдза власноручни подписи, шицки з кирилку, цо шведочи же велька часц жительства була писмена.

Руснаци з Бачинцох у маю 1851. року послали крижевскому владикови молбу писану на церковнославянским язику. Ниа, виривки:

„Многими водыханми тямко ожидахомъ время оно дожити, да ся

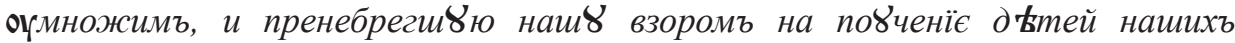
родителск४ю должностъ изполнити оүскоримъ. Сїе желаніе наше исполнися,

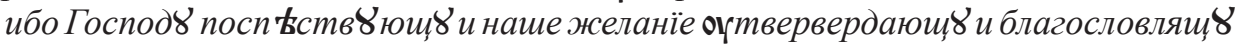
оүмножили ся єсме на толико, что насъ оүже єсть пари 55, а число домов 34, д४шъ пако 280" (АКЕ, 201/1851). Ту очиглядно нєт елементи рускей народней бешеди.

Под час револуциї 1848/49. року, або нєпостредно по нєй, и на териториї Бачки, як ше у шлїдуюцим документу наводзи, случовали ше рижни збойнїцтва, насилства, крадзи и подобни злодійства, часто и з оружийом. Наводзиме документ/преглашенє по котрим особи котри то робя подпадаю под нагли суд:

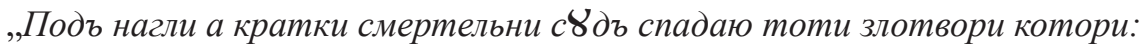

1. СУтъ челов бкоУбицй, П४стаїе, и котри на драже ичи на полю ичи у валал $\mathbf{k}$ людем на др

б) Таки с ४ть и они злобни люде котри паля, такъ ४ валалохь оу г४мнохь їакъ и на $п \mathbf{8}$ стинохъ: кедъ вецей разъ таки нєщастлици слУчаи трафятся. Непатрися ани невиберася хочи якого станю званїя іли достоинства подъ тоть смертелни судъ спадаю. ТУ ся розУмя и катонаци котри одъ Regementoxъ по тт ткали.

2. Подъ тимъ меномъ: Человтко8бици, П४стаие и на драже Гараміе роз ४мити треба и такихъ:

а) Котори по лесохъ, албо по дрУгихъ тайнихъ м tстохъ находятся и крию-

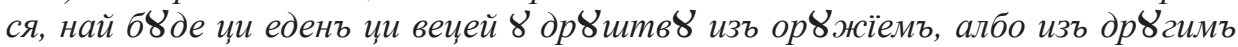
серсамомъ скотримъ смерть може огчинити или на др४же застащъ, погаращъ и пакосии вробицъ. 
b) Котри на пУ стинскихъ Карчмохъ, Чардохъ, СУвачохъ, и на дрУгихъ та-

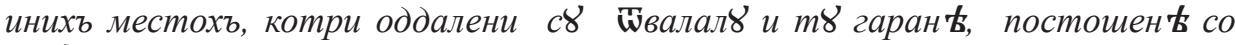
шр жіемъ робя.

c. Котори у сsипор४, с шружїемъ вселїяки Статок рогати, швци, Gиlуi ${ }^{1}$ албо минеши ${ }^{2}$ насил $\mathbf{8}$ наваля и однимаю и

d. Котри ४ Компанїи албо ४ др४жтв на 8 валаль данаедн४ ХижУ ४деря и чловека даедного окрадню, и погараю, хочи 8 такимъ сл४чаю, забїю даедного, хочи не, котрого ४лапя подъ тотъ Нагли Смертелни СУдъ спадаю, и Животъ Утрай. Aditamentum et finis. " (АПРК, без сигнатури). На другим боку текст по мадярски. Препознава ше рукопис керестурского пароха Янка Гвожджака (Миз 2016: 128-129). Текст уж бул публиковани (Рамач 2007: 284), алє графия була присподобена сучасней, та зме го ознова преписали и приложели у цалосци з оригиналну графию.

Зачувани интересантни документи котри додатно регуловали малженски одношеня. Прикладаме документ - Обвязанїе / зобовязанє, котре подписали муж и жена, повинчани як гдовец и гдовица, у котрим ше вон обовязує же убудуце будзе шорово з ню жиц и не будзе ше вецей так справовац и робиц тото цо робел. И жена му обецує вирносц, любов и старанє о дзецох и обисцу. Обвязаніее написал парох Янко Гвожджак. Текст опубликовал А. Дуличенко (Дуличенко 2009: 168-169), алє понеже направел вецей гришки у преписованю, даваме го у цалосци:

\section{"Обвязанїе}

Ја Папъ Штеф. Михаль прӥимамъ мою Жена съ мномъ в внчану с ей д ттмии, и їак на в тнччню, так и терасъ обеиу [емъ] ей и каждому котрогося сїя стварь дотикати буде, в врностъ, любовъ и прїязностъ; и їа на ей дъти таку старостъ, у хл тбу, у шматохъ мати будемъ, їак на мои власни. Кедъ же би іа ей кривду даяку уробель ю по неправди квильелъ, оганяль, пребивалъ, дапаче еще и шкаредними словами ю лаючи ображель, самъ себ $\mathbf{b}$ судъ чинимъ, кельо раз бися то трафело, тело рази все дванаць пальии заслужимъ, безъ жадного Суда бировского. Но и їа жадамъ шт неи, аби и вона по пришаги мн ' в ърностъ, любовъ прӥязность и послушенство а моему д ъвчатку материнскую любовъ и Старостъ, всегда показовала, на мою худобу якъ колвек на свою

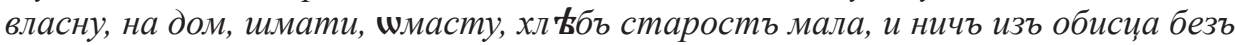
моего знаня не тьердала ".

(...) „На Сїе Шлюбоване обвязуемся собственою рукою при подписомъ моим Крестнимъ знаменіёъ и повторїаваю обвязаніее, же нигда вецеи так жити, и

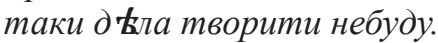

+ Папъ Штеф. Михаль, житель у Керестурь

То исто Жена его в внчана Марїа Каньюхъ ито вонъ шт неи жада шлюбуе и своимъ крестнимъ знаменїємъ потвердуеть

У Керестурь 13 Десемвра 1855.

\footnotetext{
${ }^{1}$ Гуля (од мадяр. gulya)- чупор яловкох и векших целятох на пасовиску.

${ }^{2}$ Минеш (мадяр. ménes) - чупор коньох, ергела.
} 
+ Марїа Канюхъ, вънчана Жена Пап Штеф. Михала

Пред нами : J. Gvosgják, Парох (подпис)

Viszlavszki Andri“، (АПРК, Керестур, 13. 12. 1855).

Текст писани на бешедним язику Руснацох у Бачки, з елементами церковнославянского и карпаторусинского язика, котри присутни менєй у лексики, а вецей у граматичних формох.

На писани язик Руснацох у Бачкей и Сриме при концу XVIII и у першей половки XIX вика очиглядно мал уплїв и славеносербски язик, цо мож замерковац у официйней кореспонденциї руских священїкох 303 сербским православним священством або їх церковнима велькодостойнїками. У таких писмох руски священїки до церковнославянского язика уноша и елементи сербского язика як и характеристичну ортографию за тогочасни славеносербски язик котри ше хасновал преважно у домену церковного живота. Наводзиме приклад:

„Високо-Прешсвщен ъиий Архи-Іерею, Г[оспо]дине мн 'Милостивн ъйший!-

Милостивое Прешсвщенства Вашегш Писмо, д $\mathbf{k} а$ д фвице Елене К४пнски иногда Парохіане моей касающее с, чресь жениха то д $\mathbf{6} в и ц и, к о ~ м н ~ \mathbf{~} \mathbf{\boldsymbol { w }}$ слатое, с великимь увидленіемъ вчерашним дноми читахъ: понеже честн тйшем४ Конзісторі४м४, $\mathbf{w}$ которагш Прешсвщенство Ваше изв добро познато им Łетъ бити, да азъ высочайшыл ијесаро-Кралевскыа укази не инимъ путемъ, кром' высокославнагш Конзїлі४ма, и Діецезалнагш моегш Г[оспо]дина Епископа прїимати обыкохъ. (...) Чтоже азъ на сошбщение (...)

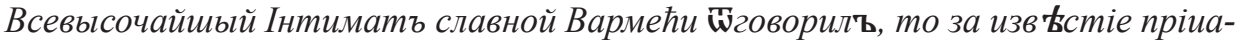
ти Високо-Преосвщенство Ваше вышепомн Г[оспо]дин сеа племенитей Ва́рмећи Вице-Шпану шслати благоизволите. (...).

Въ прочемъ вр४чающе себе у далш४ю Милость, и й Десниич шстаемт Високо-Прешсвщенства Вашегш сл४га нижсаймій Л४ка Сташински Парохъ у К४из४р ' 31 Iан४аріа [1]792.” (АКЕ, 59/1792, Коцур 31. 01. 1792).

У даєдних текстох ше находза слова або конструкциї котри нє зазначени у руским язику познєйше, алє то нє муши значиц же ше вони нє хасновали и у каждодньовей бешеди у чаше кед тексти писани. Руснаци ше од половки XVIII вика присельовали до Бачки з териториї на котру ше пресцерала юрисдикция Мукачевскей епархиї над грекокатолїками (14 жупаниї у сиверовосточней Угорскей). Медзитим, нєпреривна масовна миграция Русинох до Угорскей ше одвивала од XIV-XVIII вик 3 другого боку Карпатох, з Польскей. На спомнуту територию у Угорскей сукцесивно приходзели векши або менши габи, векши або менши групи русинских преселєнцох, Лемкох, Бойкох и Гуцулох, котри ше медзи собу могли розликовац по бешеди, етнїчних прикметох, обичайох, способе живота, привредзованя итд. (Тиводар 2011). До Бачки ше у другей половки XVIII вику присельовали Русини $30 з$ широкей териториї тедишнєй сиверовосточней Угорскей и нєт сумнїву же ше вецей або менєй медзи собу розликовац по бешеди, етнїчних и етнологийних прикметох, привредзованю, алє ше тоти розлики у новим стредку з часом у велькей мири нивеловали. Прето ше и часц лексики, хтору ище даєдни приселєнци хасновали у бешеди у другей половки XVIII вика, з часом могла затрациц. 
На концу констатуєме же у Архиви Грекокатолїцкей парохиї у Руским Керестуре зачувани писани материяли на кирилки и на русинским/руским язику з часу од конца XVIII по половку XIX вика, значни за преучованє початкох односно розвою руского писаного язика. Дакументи у найвекшей мири спадаю до сфери церковного живота або активносцох и контактох духовних особох, алє присутни и приклади материялох з обласци цивилней администрациї односно политичних власцох.

\section{Цитована литература}

Гнатюк, Володимир. «Рускі оселї в Бачцї. (В Полудневій Угорщині)». Записки Наукового Товариства ім. Шевченка, т. ХХІІ, Львів, 1898: 1-58.

[Gnatûk, Volodimir. «Ruskì oselï v Bačcï. (V Poludnevìj Ugorŝinì)». Zapiski Naukovogo Tovaristva ìm. Ševčenka, t. XXII, 1898: L'vìv 1-58]

Гнатюк, Володимир. Угроруські духовні вірші. т. І. Львів, 1902. Латяк, Д. (ред.), Нови Сад: Руске слово, 1985.

[Gnatûk, Volodimir. Ugroruskì duhovnì vìršì. t. I. L'vìv, 1902. Latâk, D. (red.), Novi Sad: Ruske slovo, 1985]

Дуличенко, Александер. Кнїжка о руским язику. Увод до рускей филологиї у документох и коментарох. Нови Сад: Дружтво за руски язик, литературу и културу, 2002.

[Duličenko, Aleksander. Knïžka o ruskim âziku. Uvod do ruskej filologiï u dokumentoh i komentaroh. Novi Sad: Družtvo za ruski âzik, literaturu i kulturu, 2002]

Дуличенко, Александер. Jugoslavo-Ruthenica II. Роботи з рускей филолотиї и uсториї. Нови Сад: Филозофски факултет Нови Сад - Руске слово, 2009.

[Duličenko, Aleksander. Jugoslavo-Ruthenica II. Roboti z ruskej filologiï i istoriï. Novi Sad: Filozofski fakultet Novi Sad - Ruske slovo, 2009]

Ковач, Михайхло. «Розвой писаного слова и сучасна видавательна дїялносц у нас». Нова думка, 4. Вуковар: Союз русинів-українців Хорватії, 1973, 41-45.

[Kovač, Mihajhlo. «Rozvoj pisanogo slova i sučasna vidavatel'na diâlnosc u nas». Nova dumka, 4. Vukovar: Soûz rusinìv-ukraïncìv Horvatiï, 1973, 41-45]

Ковач, Михайло. «Шлїдами зазберовачох народних духовних скарбох у нас». Нова думка, 16. Вуковар: Союз русинів- українців Хорватії, 1977, 49-46.

[Kovač, Mihajlo. «Šlïdami zazberovačoh narodnih duhovnih skarboh u nas». Nova dumka, 16. Vukovar: Soûz rusinìv-ukraïncìv Horvatiï, 1977, 49-46]

Костельник, Гавриїл. Liber memorabilium грекокатолїцкей парохиї бачкерестурскей. Нови Сад: Союз Руснацох и Українцох Югославиї, 1998.

[Kostel'nik, Gavriïl. Liber memorabilium grekokatolïckej parohiï bačkeresturskej. Novi Sad: Soûz Rusnacoh i Ukraïncoh Ûgoslaviï, 1998]

Костельник, Гавриїл. Проза на руским литературним язику. Нови Сад: Руске слово, 2011.

[Kostel'nik, Gavriïl. Proza na ruskim literaturnim âziku.Novi Sad: Ruske slovo, 2011]

Миз, Роман. Священїки дакедишнього Осєцкого викарията. Нови Сад Петроварадин: Парохия св. Петра и Павла Нови Сад - „Махіта“ - друкарня и видавательна хижа, Петроварадин, 2016.

[Miz, Roman. Svâŝenïki dakedišn'ogo Osêckogo vikariâta. Novi Sad - Petrovaradin: Parohiâ sv. Petra i Pavla Novi Sad - „Maxima“ - drukarnâ i vidavatelna hiža, Petrovaradin, 2016] 
Рамач Фурман, Анамария. «Особлївосци консонатизма єдней рускей рукописней кнїжки з початку XX вику».

Шветлосц, 4/2019. Нови Сад: Руске слово, 2019, 25-45.

[Ramač Furman, Anamariâ. «Osoblïvosci konsonatizma êdnej ruskej rukopisnej knïžki z počatku XX viku». Švetlosc, 4/2019. Novi Sad: Ruske slovo, 2019, 25-45]

Рамач, Янко. Руснаци у Южней Угорскей (1745-1918). Нови Сад: Войводянска академия наукох и уметносцох, 2007.

[Ramač, Ânko. Rusnaci u Ûžnej Ugorskej (1745-1918). Novi Sad: Vojvodânska akademiâ naukoh i umetnoscoh, 2007]

Рамач, Јанко. „Почеци националног препорода Русина у Јужној Угарској у првој половини 19. века“". Годишњак филозофског факултета у Новом Саду, књ. XXXV-1, Филозофски факултет Нови Сад Нови Сад, 2010, 255-266.

[Ramač, Janko. «Počeci nacionalnog preporoda Rusina u Južnoj Ugarskoj u prvoj polovini19. veka». Godišnjak filozofskog fakulteta u Novom Sadu, knj. XXXV-1, Filozofski fakultet Novi Sad, Novi Sad, 2010, 255-266]

Рамач, Янко. «Тексти апокрифа "Хождениє Богородици по муках" у руских рукописних зборнїкох». Шветлосц, 1/2011. Нови Сад: Руске слово, 2011, 49-70.

[Ramač, Ânko. «Teksti apokrifa "Hoždeniê Bogorodici po mukah" u ruskih rukopisnih zbornïkoh». Švetlosc, 1/2011. Novi Sad: Ruske slovo, 2011, 49-70]

Рамач, Янко. «Матеріали до вивчення апокрифів з рукописних збірок русинів Південної Угорщини (XIX ст)». Проблеми славянознавства/Problems of Slavonic studies, Випуск/Issue 65. Лівів - Львівський національний університет, 2016, 158-166.

[Ramač, Ânko. «Materìali do vivčennâ apokrifîv z rukopisnih zbìrok rusinìv Pìvdennoï Ugorŝini (XIX st)». Problemi slavânoznavstva/Problems of Slavonic studies, Vipusk/ Issue 65. Lìvìv - L'vìvs'kij nacìnal'nij unìversitet, 2016, 158-166]

Рамач, Янко. «Подоби Христа, апостолох и святих у апокрифох Руснацох у Южней Угорскей». [У:] А. Дуличенко, М. Номати (ред). Славянская микрофилология. Slavica Tartuensia XI - Slavic Euroasian Studies 34. Sapporo - Tartu: SlavicEuroasian Research Center - Slaavi Filoloogia Osakond, 2018, 273-289.

[Ramač, Ânko. «Podobi Hrista, apostoloh i svâtih u apokrifoh Rusnacoh u Ûžnej Ugorskej». [U:] A. Duličenko, - M. Nomati (red). Slavânskaâ mikrofilologiâ. Slavica Tartuensia XI - Slavic Euroasian Studies 34. Sapporo-Tartu: Slavic-Euroasian Research Center - Slaavi Filoloogia Osakond, 2018a, 273-289]

Рамач, Янко. Світогляд русинів Південної Угорщини крізь призму апокрифів з їх рукописних збірників з XVIII та XIX стст. У: Српска славистика. Колективна моногхрафија, т. II. Београд: Савез Савез славистичких друштава Србије, 2018б, 321-332.

[Ramač, Ânko. Svìtoglâd rusinìv Pìvdennoï Ugorŝini krìz' prizmu apokrifîv z ïh rukopisnih zbìrnikiv z XVIII ta XIX stst. U: Srpska slavistika. Kolektivna monoghrafija, t. II. Beograd: Savez Savez slavističkih društava Srbije, 2018b, 321-332]

Рамач, Юлиян. Граматика руского язика. Београд: Завод за уџбенике и наставна средства, 2002.

[Ramač, Ûliân. Gramatika ruskogo âzika. Beograd: Zavod za udžbenike i nastavna sredstva, 2002]

Тамаш, Юлиян. История рускей литератури, Београд: Завод за уџбенике и наставна средства. 1997.

[Tamaš, Ûliân. Istoriâ ruskej literaturi, Beograd: Zavod za udžbenike i nastavna sredstva. 1997] 
Тиводар, Михайло. Етнографія Закарпаття. Ужгород: Гражда, 2011.

[Tivodar, Mihajlo. Etnografiâ Zakarpattâ. Užgorod: Gražda, 2011]

Тихи, Ф. «Дві старібачванско-рускі вірші». Руски календар за южнославянских Русинох 1932. Руски Керестур: Руске народне просвитне дружтво., 1932,

[Tihi, František. «Dvì starì bačvansko-ruskì vìršì». Ruski kalendar za ûžnoslavânskih Rusinoh 1932.RuskiKerestur: Ruske narodne prosvitne družtvo, 1932, 78-82.]

Tichý, F. «Jihoslavanští Rusíni». Slovanský přehled,1928, XX, č. 3, leden, s. 30.

Tichý, F. Československé písně v Moskevskěm zpevníku. Praha a Bratislava, 1931.

Франко, Іван. Апокрифи і легенди з українських рукописів. т. II, Апокрифи новозавітні. А. Апокрифічні

евангелія. Львів, 1899. Львів: Львівський національний університет, 2006.

[Franko, İvan. Apokrifi ì legendi z ukraïns'kih rukopisìv. t. II, Apokrifi novozavìtnì. A. Apokrifičnì evangeliâ.

L'vìv, 1899. L'vìv: L'vìvs' kij nacìonal'nij unìversitet, 2006]

Франко, Іван. Апокрифи і легенди з українських рукописів. т. IV. Апокрифи есхатологічні. Львів, 1906. Львів: Львівський національний університет, 2006.

[Franko, İvan. Apokrifi ì legendi z ukraïns'kih rukopisìv. t. IV. Apokrifi eshatologìčnì. L'vìv, 1906. L'vìv: L'vìvs'kij nacìonal'nij unìversitet, 2006]

Удвари, Иштван. «Нєпознате писмо Георгия Росия на мадярску Горнїцу». Шветлосц, 2/1989. Нови Сад: Руске слово, 1989, 246-258.

[Udvari, Ištvan. «Nêpoznate pismo Georgiâ Rosiâ na madârsku Gornïcu». Švetlosc, 2/1989. Novi Sad: Ruske slovo, 1989, 246-258]

Цап, М. Микола. Церква и школа у Коцуре. Прилоги и жридла. Нови Сад: Грекокатолїцка парохия св. Петра и Павла Нови Сад, 1996.

[Cap, M. Mikola. Cerkva i škola u Kocure. Prilogi i žridla. Novi Sad: Grekokatolïcka parohiâ sv. Petra i Pavla Novi Sad, 1996]

Gavrilović, Slavko. «Rusini u Bačkoj i sremu od sredine XVIII do sredine XIX veka». Godišnjak Društva istoričara Vojvodine. Novi Sad: Društvo istoričara Vojvodine, 1977, 153-215.

\section{Жридла}

Архив Крижевскей епархиї, Крижевци - Arhiv Križevačke eparhije, Križevci (AКE) [Arhiv Križevskej eparhiï, Križevci - Arhiv Križevačke eparhije, Križevci (AKE)]

Архив Парохиї у Руским Керестуре (АПРК) - приватни писма без сигнатурох и матрикули кресцених, винчаних и умартих.

[Arhiv Parohiï u Ruskim Keresture (APRK) - privatni pisma bez signaturoh i matrikuli krescenih, vinčanih i umartih] 


\title{
Janko Ramač
}

\author{
THE BEGINNINGS OF CYRILLIC LITERACY OF THE RUTHENIANS \\ IN BAČKA AND SREM FROM THE MID-1 $8^{\text {th }}$ to THE MID-19 ${ }^{\text {th }}$ CENTURIES
}

\begin{abstract}
Summary
The article presents, describes and includes parts of written sources in the Ruthenian/Rusyn and Church Slavonic languages which are important for the study of the beginnings of Ruthenian literacy in Bačka and Srem from the mid- $18^{\text {th }}$ to the mid- $19^{\text {th }}$ centuries. In the former studies of the history of the Ruthenian language, only a smaller number of these documents have been mentioned, without thorough analysis. On the basis of the analysis of the extant sources, it can be concluded that until the late $18^{\text {th }}$ century these texts were written in Cyrillic, Church Slavonic script, mainly in Church Slavonic, or in a mixture of the Church Slavonic and Carpatho-Ruthenian standardlanguages of that time. In these texts there are no elements of the vernacular of the Ruthenians in Bačka. It can be explained by the fact that they were mainly written by Ruthenian priests who were, by origin, from the upper parts of Hungary, from the territory of the jurisdiction of the Diocese of Mukachevo which extended over the Greek Catholics. Only the documents from the 1840s written in Cyrillic, Church Slavonic and civil scripts were preserved. Besides Church Slavonic, there was also a mixture of the Church Slavonic language and the vernacular of the Ruthenians in Bačka and Srem, and, partly, a mixture of Russian Church Slavonic and vernacular Serbian languages used by spiritual and lay persons.
\end{abstract}

Keywords: Ruthenians in Bačka and Srem, Cyrillic literacy, Church Slavonic language, vernacular, mixture of Russian Church Slavonic and vernacular Serbian languages. 